\title{
Retraction Notice to "Computer mediated communication for construction-supported constructivism in communication and cultural learning" [International Journal of Communication and Society 1(1) (2019) 34-42]
}

\author{
Wayan Sintawati a,1,* \\ a Nanjing Normal University, China \\ 1'wayansintawati@gmail.com
}

\section{ARTICLE INFO}

\section{Article history}

Retraction Notice to "Computer mediated communication for construction-supported

constructivism in communication and cultural learning" [International Journal of Communication and Society 1(1) (2019) 34-42]

DOI:

https://doi.org/10.31763/ijcs.v1i2.49

\begin{abstract}
Following a rigorous, carefully concerns and considered review of the article published in International Journal of Communication and Society toarticleentitled "Computer mediated communication for constructionsupported constructivism in communication and cultural learning" [International Journal of Communication and Society Vol 1, No 1, 2019, 34-42], DOI: https://doi.org/10.31763/ijcs.v1i1.29. This paper has been found to be in violation of the International Journal of Communication and Society Publication principles and has been retracted. This article has been retracted at the request of the Supervisor, Rustam Shadiev (Nanjing Normal University, China), of the author, Wayan Sintawati (Nanjing Normal University, China), because the author didn't communicate with him to publish the research work in this journal and didn't write his name on the article as responsible to teamwork effort. This practice is count as the unethical publication of the International Journal of Communication and Society.
\end{abstract}

This is an open access article under the CC-BY-SA license. 